Book Reviews 


\title{
John Connelly's Long March through East European History
}

\section{Connelly, John. From Peoples into Nations: A History of Eastern Europe}

\author{
Princeton: Princeton University Press, 2020. Pp. viii +956.
}

\author{
Gary B. Cohen
}

Department of History (Emeritus), University of Minnesota, Minneapolis and St. Paul, Minnesota, USA

John Connelly, a member of the history faculty at the University of California, Berkeley, for the last quarter century, has produced what will surely stand as a landmark among grand syntheses on the modern history of Eastern Europe. The book title uses the geographical designation favored during the Cold War, but the subject is more precisely East Central Europe, a term that Connelly uses interchangeably with Eastern Europe to designate the lands lying between Germany and Austria in the west and the former components of the Soviet Union to the east.

A number of survey histories of the region appeared during the Cold War and soon after its end, most of them intended for college or university instruction and much shorter than Connelly's. Many of these remained in print for only a short period. Notable exceptions are Lonnie Johnson's 380-page Central Europe: Enemies, Neighbors, Friends (Oxford, first ed., 1996; third ed., 2011), and Ivan T. Berend's more analytic and interpretive three volumes, History Derailed: Central and Eastern Europe in the Long Nineteenth Century (Berkeley, 2003); Decades of Crisis: Central and Eastern Europe before World War II (Berkeley, 1998); and Central and Eastern Europe 1944-1993: Detour from the Periphery to the Periphery (Cambridge, 1996), totaling some 1,070 pages of text with all three volumes still available at this time. Survey histories covering merely the twentieth century and intended largely for instructional use, such as R. J. Crampton's Eastern Europe in the Twentieth Century-And After (London, first ed., 1994; second ed., 1997), and Joseph Rothschild and, from the third edition onward, Nancy M. Wingfield's Return to Diversity: A Political History of East Central Europe since World War II (New York, first ed., 1988; fourth ed., 2007) have also remained in print for more than two decades each.

Encompassing 800 pages of text and 125 pages of endnotes, Connelly's tome nearly matches Berend's work in scale; but he presents more of a grand synthetic narrative, which should appeal to general readers as well as students if they are not intimidated by the length. Scholars will find much to ponder in Connelly's interpretations of many developments, and all readers will be impressed by his citing an enormous number and range of published sources in German, French, Polish, Czech, Croatian, Serbian, and English. A mostly lean, readable writing style helps the presentation, although numerous instances of missing prepositions and inconsistencies in terminology and the spellings of names suggest that the length overstretched the author's and editors' capacities for copyediting. Connelly makes many interesting analytic and interpretive points, but he typically embeds them in the narrative or offers them in concluding statements, not as the focus for analytically organized chapter sections. Many readers will surely appreciate the absence of abstruse analytic concepts and jargon. Yet while free of any formal analytic overhang, the text is studded with many important insights along the way and not a few sparkling bons mots.

In contrast to Pieter M. Judson's recent synthesis, The Habsburg Monarchy: A New History (Cambridge, MA, 2016), no explicit revisionist impulse motivates Connelly's overall reading of the 
modern history of East Central Europe. In fact, he embraces many traditional viewpoints in framing the book. At base he sees this region as "a crossroads of religions, languages, and culinary tastes and the shatter zone of empires" (787). Here many culturally and historically distinct peoples have coexisted and were ruled for long periods by imperial regimes before they achieved national self-government. These circumstances have given the region a particular history and character compared to other parts of Europe and the larger North Atlantic world. Connelly argues against much recent scholarship that envisions a historically constructed and conditioned character of national identification in the region and the contingent fall of the multiethnic imperial states at the beginning of the twentieth century. He posits instead the prior existence of distinct peoples here, who were defined already before the nineteenth century if not necessarily by an expressed popular group consciousness but at least in objective terms by their particular languages, group cultures, and unequal access as groups to economic resources and political power. These inequalities and the threats to many of the peoples' continued existence from assimilative efforts by the multiethnic imperial states provided the preconditions, in Connelly's view, for mobilizing national movements after the late eighteenth century and eventually for dogged efforts to achieve national self-government.

Interpretively then, Connelly stands close to many earlier historians of European national movements such as Miroslav Hroch in arguing that one could not construct national movements and modern nations ex nihilo and that there must be some preexisting linguistic, cultural, historic, economic, political, and/or geographic conditions that distinguished each group. Accordingly, Connelly rejects constructivist accounts of nation formation and nationalist politics such as those put forth by Ernest Gellner, Etienne Balibar, and Rogers Brubaker. ${ }^{1}$ This new synthesis on East Central European history thus lands on the traditional side in important aspects of its general approach, but this does not at all preclude presenting original readings of many events and developments.

After offering some broad brushstrokes on earlier eras, Connelly begins his account with the intellectuals who pioneered doctrines of linguistic nationalism in East Central Europe after the late eighteenth century. Discussion of the nineteenth century takes up only 300 out of the 800 pages of text in the book, while the twentieth century-and particularly the decades of communist and now postcommunist rulegets the closest attention. Connelly devotes nearly 300 pages to the period since 1945 . Overall, the treatment of the twentieth century strikes this reader as the most insightful and persuasive part of the book.

Connelly's discussion of the nineteenth century and the first decades of the twentieth gives the greatest attention to the territories included in the Habsburg monarchy. The distinct experiences of the Prussian and Russian sectors of divided Poland and of Southeastern Europe under Turkish rule receive briefer treatment until Connelly takes up the issues of socialism versus nationalism in chapter 10 and peasant utopias in chapter 11. The long-term impacts of the tsarist and Ottoman empires on law, public administration, civil society, and social structures in their East Central European lands draw only limited comment.

In discussing the century before World War I, Connelly focuses on the evolution of nationalist ideology in East Central Europe and the major political developments in the relationship of national movements to the multiethnic imperial states. The imperial states provided the context for the growth of modern national movements and their political action over the long nineteenth century, but as such those states are little more than epiphenomenal in the narrative. Historians such as Gerald Stourzh, John Boyer, Pieter Judson, John Deak, and this writer have found greater significance than does Connelly for the long-term development of parts of the region in the Habsburg monarchy's advances in modern government, law, and public services during the nineteenth century. Connelly judges that "the Habsburgs never made 'empire' a forceful or self-confident project" (107). He allows that even if

\footnotetext{
${ }^{1}$ See Miroslav Hroch, "From National Movement to the Fully-Formed Nation: The Nation-Building Process in Europe," New Left Review 198 (Mar.-Apr. 1993): 3-20; idem, Na prahu národní existence: touha a skutečnost (Prague, 1999); idem, In the National Interest. Demands and Goals of European National Movements of the Nineteenth Century: A Comparative Perspective (Prague, 2000); idem, European Nations, Explaining Their Formation (London, 2015); Ernest Gellner, Nations and Nationalism (Ithaca, NY, 1983), 49, 55; Etiènne Balibar, “The Nation Form: History and Ideology," in Becoming National: A Reader, ed. Geoff Eley and Ronald Suny (New York, 1996), 138, 140; and Rogers Brubaker and Frederick Cooper, "Beyond 'Identity,'" Theory and Society 29 (2000): 1-47; and Rogers Brubaker, Nationalism Reframed: Nationhood and the National Question in the New Europe (Cambridge, 1996), 1-22.
} 
the dualist constitutional settlement of 1867 "provided a stable legal platform for state consolidation and steady economic progress," it could not satisfy the desires of nationalist elites for "self-government and legally binding protection of their cultures" (207-8). This reality eventually doomed the monarchy, for "as the monarchy reformed, it made itself less reformable ..., and as it entered the imperial age, it was less an empire than ever before" (209).

In the decades before the outbreak of the Great War, Connelly sees weak popular loyalties to Habsburg rule and growing "fear, miscalculation, and dereliction of duty" by government leaders in Austria and Hungary (298). This is not as stark and sweeping an indictment of a state irrevocably doomed by deficit and decay as one finds, for example, in A. J. P. Taylor's classic The Habsburg Monarchy, 1809-1918 (London, 1948); but with the ineluctable advance of the national movements and the inability of the Austrian and Hungarian states to grant them meaningful self-government, Connelly presents the old dynastic state as condemned to decline and eventual dissolution. Consistent with the view that the die was cast for the Habsburg monarchy already before 1914, Connelly gives little attention to the wartime dictatorship and the growing exhaustion of the Austrian and Hungarian state administrations after 1916, which Maureen Healy, Rudolf Kučera, Jonathan Gumz, and others have examined so persuasively and have identified as critical for defeating the monarchy on the home front and aiding its final collapse. ${ }^{2}$

With his primary focus on the rise of the national political movements, Connelly gives great attention to the ideas and political initiatives of leading nationalist activists over the nineteenth century. Compared to shorter survey histories, there is space here for vivid descriptions of individual political actors. Social change gets less coverage, and one finds little, for instance, about the social and economic consequences of peasant emancipation and the advance of capitalist agriculture for peasants and landowners or about mass migration after the mid-nineteenth century within Europe and across the Atlantic. Similarly, one cannot look to this book for much on women's experience or gender issues in East Central Europe during the nineteenth century, despite the growing body of scholarship on these subjects in recent years.

More relevant to Connelly's central concerns are the social dynamics of nationalist activists' work to mobilize popular followings, but in this regard one finds significant gaps in the discussion. Connelly offers little in the chapters on the nineteenth century on the sustained efforts of many nationalist activists to combat ambiguous national identities, national indifference, or the assimilation of potential adherents to rival nationalities. These were significant phenomena in bilingual communities and areas where more concentrated populations of differing languages and/or religions bordered each other, such as in Bohemia and Moravia, Upper Silesia, parts of Galicia and Bukovina, and southern Styria and Carinthia. In these locales during the late nineteenth and early twentieth centuries, nationalist activists campaigned to aid farmers who spoke their language, save farmsteads for their own nationality, and sustain nationally motivated economic boycotts. ${ }^{3}$ In places where parents could choose among local schools with differing languages of instruction, nationalist politicians looked for ways to prevent children who spoke their national language at home from attending schools where the language was that of a national adversary. In Moravia, for instance, such efforts resulted in the adoption of the Lex Perek as part of the Moravian Compromise in $1905 .{ }^{4}$ Even as late as the years

\footnotetext{
${ }^{2}$ See Judson, The Habsburg Empire; John Deak, Forging a Multinational State: State Making in Imperial Austria from the Enlightenment to the First World War (Stanford, 2015); Gary B. Cohen, Education and Middle-Class Society in Imperial Austria, 1848-1918 (West Lafayette, 1996); idem, "Nationalist Politics and the Dynamics of State and Civil Society in the Habsburg Monarchy, 1867-1914," Central European History 40 (2007): 241-78; Jana Osterkamp, ed., Kooperatives Imperium. Politische Zusammenarbeit in der späten Habsburgermonarchie (Göttingen, 2018); Franz Adlgasser and Fredrik Lindström, eds., The Habsburg Civil Service and Beyond (Vienna, 2019).

${ }^{3}$ See Tara Zahra, Kidnapped Souls: National Indifference and the Battle for Children in the Bohemian Lands, 1900-1948 (Ithaca, NY, 2008); Pieter M. Judson, Guardians of the Nation: Activists on the Language Frontiers of Imperial Austria (Cambridge, MA, 2006); and Jeremy King, Budweisers into Czechs and Germans: A Local History of Bohemian Politics, 18481948 (Princeton, 2002).

${ }^{4}$ On the Lex Perek, see Zahra, Kidnapped Souls, 13-48; Gerald Stourzh, Die Gleichberechtigung der Nationalitäten in der Verfassung und Verwaltung Österreichs 1848-1918 (Vienna, 1985), 216-21, 245, 306-16; idem, "The Ethnicizing of Politics and 'National Indifference' in Late Imperial Austria," in Stourzh, Der Umfang der österreichischen Geschichte. Ausgewählte Studien 1990-2010 (Vienna, 2011), 283-323, at 312-19.
} 
of the Nazi occupation of Bohemia and Moravia, there were some in the native population who tried to renegotiate their national loyalties to please the new Reich German overlords. ${ }^{5}$

National identities did capture the allegiances of the great majority of people in East Central Europe by the early twentieth century. Connelly's strong focus on that path of development in the chapters on the nineteenth century tends to filter out the challenges to nationalist mobilization posed by ambiguous or mutable identities and national indifference or simply the expression of national loyalties alongside persisting allegiances to particular regions, the historic crown lands, or to the imperial states and their sovereigns. At the beginning of the book, Connelly strikes a dismissive tone when he writes about late nineteenth-century Bohemia, for instance, that "Politicians of that time and place did not run on a platform of 'indifference'; non-national identity was not a conviction, let alone a passion" (23). Later, in the conclusion of the book, Connelly briefly notes nationalist activists' efforts to combat indifference, ambiguity, and mutability in national loyalties (788), but earlier he misses opportunities to describe more concretely the grassroots sociopolitical dynamics of building the national movements. The larger point here is that the development of modern popular civic values and national political loyalties in East Central Europe had an interesting history as sociopolitical process that Connelly tends to skip over.

His account of 1918-19 and the following two decades are largely the story of how nationalist movements in East Central Europe and their leaders finally broke free of the old imperial states but then faced enormous challenges in securing new borders and constructing viable new polities. Defeat in a long war that the leaders of the imperial states had chosen to fight, growing agitation by the end for outright national independence, and eventually support for the nationalist causes by the victorious belligerent powers opened the door for dismembering the imperial states and creating new national polities. In line with Connelly's thinner treatment of Russian and Ottoman rule over their East Central European lands, he gives little attention to how Russia lost its Polish territories during World War I and the Russian Revolution until the narrative reaches the Polish-Soviet War of 1919-20.

Geographic balances are more satisfying in Connelly's discussion of the two decades after 1918. Presenting a rich tapestry of events and leading personalities, he captures persuasively the major domestic and international challenges that confronted the leading political forces in each country. He gives due attention to the special difficulties that the Polish, Czechoslovak, Yugoslav, and Romanian states faced in trying to unite territories with diverse histories and social structures and to the wide gaps between the political elites and the general populations in all the East Central European countries. Connelly notes the major concerns of public policy in the era, particularly the problems of underdeveloped peasant agriculture and rural poverty, although in general he focuses more on political developments and movements than on economics as such. The narrative conveys well the major political contests and turning points of the era, aided by incisive treatments of the issues at stake and vivid characterizations of major leaders. Some readers may feel overwhelmed at times by the narrative detail, particularly when Yugoslav or Romanian politics drifted into chaos; but Connelly generally maintains a sharp focus on the important outcomes.

To capture even better the significance of developments during the interwar years, it would have been helpful to draw back from the events more often to analyze the larger questions in a more thematic way. In this regard, even after the publication of so much valuable scholarship over the last seventy-five years, one can still profit from reading Hugh Seton-Watson's pioneering overview, Eastern Europe between the Wars, 1918-1941 (Cambridge, 1945), in which he laid out with great insight the major challenges for social, political, and economic development across the whole region.

Capturing the experience of World War II in East Central Europe represents a formidable challenge for writing a survey history of the region, which Connelly meets impressively. He succeeds in dealing with the East Central European dimensions of the diplomatic and military history of the war, the Nazi and Soviet expansion into these lands, and the Nazi policies of genocide without recapitulating the general history of the war and the German and Soviet roles. Along the way, Connelly deftly examines both the performance of East Central European leaders and the broader experience of the native

${ }^{5}$ Chad Bryant, Prague in Black: Nazi Rule and Czech Nationalism (Cambridge, MA, 2007), 50-57, 67-76. 
populations. The thirty-five pages devoted to the Holocaust captures persuasively the work of the Nazi forces as well as the roles of local elites and elements of the general population without losing sight of the horrific human suffering. This represents one of the most impressive short accounts of the destruction of the Jewish population in East Central Europe to be found anywhere.

Connelly's treatment of the immediate post-1945 years and the succeeding four decades of communist rule displays many of the same strengths as that of the interwar period. His masterful early work on the transformation of higher education in Poland, the Czech lands, and East Germany during the first years of communist rule prepared him well for examining the contradictions and contingencies involved in the initial "people's democracy" phase of building the new communist regimes. ${ }^{6}$ Here again, Connelly offers a richly textured narrative to depict how these societies were open to systemic change after the tribulations of the 1930s and the war years, and how many communist leaders initially showed some patience in dealing with the particular conditions in their countries as they prepared for eventually constructing Soviet-style governing systems. Connelly is notably unsparing as he describes how the new communist government leaders exploited nationalist sentiments and identified both class and national enemies.

The dynamism of the communist regimes in their first decades comes across with great clarity, but that dynamism also entailed moments of social and political instability, particularly after the death of Stalin, wherever the Soviet and native communist leaders initiated reforms. Connelly depicts vividly the great crises and turning points: the Tito-Stalin split in 1948; the East German workers' uprising in 1953; the crises of 1956 in Poland and Hungary; the 1968 reform movement in Czechoslovakia and ensuing invasion by Warsaw Treaty forces; Poland's workers' strikes, the 1968 crisis, the fall of Gomulka in 1970, and the rise of the Solidarity movement a decade later; and finally the events that led to the collapse of the communist governments across the region in 1989. The narrative is studded with compelling vignettes about critical moments, some of the leading actors, and the impact of communist policies on society and everyday life. One notices here and there that more sympathetic figures such as Imre Nagy, Alexander Dubček, and Josip Broz Tito and prominent dissident intellectuals get greater attention than important but more orthodox communist stalwarts such as Bolesław Bierut, Gheorghe Gheorgiu-Dej, or Gustav Husák. The chronology of crucial events can be a little sketchy or confusing in places, such as in the account of the disintegration of Hungarian communist rule in 1988-89 (718-20). Connelly mentions the Solidarity trade union movement in Poland several times before he has treated its formation.

Throughout, though, Connelly offers a rich, colorful narrative for the history of communist governments in East Central Europe and their ultimate downfall. It is also a notably intelligent discussion that identifies the pressures that the governments exerted on society, where they encountered impediments or outright resistance, and the social and economic consequences of the major political developments. Even more for the communist era than for the interwar period, though, one can argue that a greater reliance on some key analytic concepts and more examination of structural relationships would help readers in seeing deeper meanings. One need not go so far as to adopt a thoroughgoing-and potentially constricting-theoretical framing like that which the political scientist Zbigniew Brzezinski deployed back in the 1960s in his The Soviet Bloc: Unity and Conflict (Cambridge, MA, 1960; rev. enlarged ed., 1967). More apposite would be an approach like George Schöpflin's in his Politics in Eastern Europe (Cambridge, MA, 1993), which offers a conceptually aware account and teases out the larger significance of events and political relationships that Connelly's narrative sometimes misses.

What sort of analytic concepts and terms do I have in mind? Many scholars would argue, for instance, that a lack of popularly accepted legitimacy from the founding of the communist governments in East Central Europe onward was a point of vulnerability for all of them except Yugoslavia and perhaps Bulgaria. It is telling, though, that Connelly's first use of the term "legitimacy," at least that this reader found, comes only as late as page 686, at the beginning of chapter 14, "The Unraveling of Communism." The problem of legitimacy is certainly implicit in the narrative before then, but Connelly is notably sparing in using even simple analytic terms such as this.

\footnotetext{
${ }^{6}$ John Connelly, The Captive University: The Sovietization of East German, Czech, and Polish Higher Education, 1945-1956 (Chapel Hill, 2000).
} 
In discussing the long-term weakening of communist rule in Poland, Hungary, and Yugoslavia during the 1980s, for example, it would help to write more explicitly about processes of political decay or, to borrow a concept favored by neo-Marxists, the growing inability of the communist parties' apparatus to reproduce itself, which led to a gradual hollowing out of communist party rule in several of the countries. ${ }^{7}$ Writing more explicitly about such structural issues might have led Connelly to take greater note, for instance, of the Polish United Workers' Party's failure to recover the numbers and strength lost during the Solidarity crisis or the Hungarian government's growing reliance on organizations in the society other than the party well before the situation became critical after late 1988. More explicit discussion of how the structures of communist rule weakened over the course of the 1980s, whether by the visible decay of parts of the party apparatus in Poland, Hungary, and Yugoslavia or an increasing rigidification in hard-line Czechoslovakia, East Germany, Romania, and Bulgaria would strengthen Connelly's explanation of how what had been powerful dictatorships for much of four decades collapsed so quickly when the tipping points came in 1989 and 1990.

The last two substantive chapters address the major developments over the thirty years since the fall of the communist governments. Chapter 26 manages in the space of twenty-two pages to encapsulate nicely the political, social, and economic problems and the processes, dating back to the 1970s, that led eventually to the disastrous wars of Yugoslav succession. Connelly takes due note of the contributing actions by politicians, intellectuals, and military leaders within Yugoslavia as well as by leaders in the international community. The last chapter takes up the political and economic transformations since 1989 across the whole region. This is no easy task, but Connelly does well by highlighting the challenges of organizing new political parties and privatizing the socialist economies, the oscillations between left-leaning and right-leaning governments, and the continuing lure of authoritarian leadership. All the countries in the region get some attention here but for Albania, which gets no treatment anywhere in the book. Connelly argues that except for the conflicts in the former Yugoslavia and the dissolution of Czechoslovakia, nationalism has played less of a role in the politics of the postcommunist states than might have been expected. Certainly, though, there have been political leaders and parties in all these countries who have tried to play nationalist cards.

In the conclusion, Connelly sums up what he believes has made the character and functions of national loyalties a particular defining factor in the modern history of East Central Europe. He reiterates that national identities here rested above all on the experience of numerically smaller peoples in the "shadow zones of empires" who were defined by their distinct cultures and up to the beginning of the twentieth century faced the "humiliation of social and national oppression" (797). Connelly rejects any more universal theories of constructing national identities and nationalist politics such as those of Ernest Gellner, Eric J. Hobsbawm, or Benedict Anderson. In Connelly's view, neither modern capitalism in general nor "print capitalism," but the reality of peoples in East Central Europe who were already defined by their language and history and by their experiencing subaltern status and threats to their continued existence provided the foundations for building national political movements after the late eighteenth or early nineteenth century (796-98).

In the end, Connelly's master narrative views the formation of national political movements to assure group survival, their advancing to claim self-government, and eventually the founding of national states as constituting an ineluctable chain of development in East Central Europe. When one considers popular experience and political action in the aggregate, one cannot deny that this is what happened over the long run. This interpretation, however, tends to discount much fruitful research from the last forty years that has shown that the processes of developing modern national loyalties and building national political movements were complex and arduous efforts, far from linear in their advance, and often not entirely successful in winning over all their targeted constituencies. Drawing from that body of research, produced initially in large part by North American scholars, one can argue that Connelly simplifies the processes of defining loyalties and filters out the choices that individuals in various parts of East Central Europe had along the way in adopting one allegiance

\footnotetext{
${ }^{7}$ On political decay as a general phenomenon, see Samuel P. Huntington, "Political Development and Political Decay," World Politics 17, no. 3 (Apr. 1965): 386-430.
} 
over another or even to avoid, if they could, a fixed and exclusive allegiance, particularly where there was much mingling of people with differing mother tongues and/or religions. Thereby, Connelly also simplifies somewhat the picture of the nationalist activists' work, as they often had to labor long and hard to develop firm national loyalties among their targeted constituencies, combat ambivalence or assimilation, and discipline their followings' political and social relations with national adversaries. Connelly certainly recognizes the increasing dynamism of these societies as the early modern hierarchies of corporate status groups gave way to class structures, modern agriculture and industry advanced, and migration increased. That social and economic dynamism, however, opened new possibilities for individuals to adopt or change their group political loyalties and constituted important circumstances in the processes of building national movements.

This is not at all to deny that national loyalties and nationalist political formations eventually did become dominant in the East Central European public sphere or to claim a contingency in the processes of development that would posit that the majority of people in the region might well have adopted nonnational loyalties as their primary political allegiance. In his summing up, Connelly imputes such a view of the contingency of national identification to the historians who have argued for the significance of national indifference and mutability in East Central Europe (790). ${ }^{8} \mathrm{I}$ am not persuaded, though, by this reading of the works of Judson, Tara Zahra, Jeremy King, Chad Bryant, James Bjork, Tomasz Kamusella, myself, or more recently, Brendan Karch. Rather, I believe that they have argued broadly for the socially and politically conditioned and constructed character of modern popular national loyalties and nationalist political movements. At the micro level of individuals and localities, these historians have found realities of local or regional group identities, often coexisting with national loyalties, but also ambiguity, mutability, or indifference regarding national loyalty, which persisted in some situations into the early twentieth century. These authors have not claimed as a counterfactual possibility at the macro level a nonnational alternative to the development of nationalist movements and popular national political loyalties, developments that were in fact realized by the majority of people, even if not by all, in much of East Central Europe by the early decades of the twentieth century. ${ }^{9}$

Clearly, John Connelly has produced a masterful and generally persuasive synthesis on the political development and sociopolitical experience of East Central Europe in the twentieth century, one from which readers will learn much. This is a considerable achievement. His treatment of the nineteenth century also has many strengths, particularly in discussing the rise of nationalist ideology and the general advance of the nationalist political movements. If his account here is less satisfying than the treatment of the twentieth century, this is for several reasons. The chapters on the decades from 1918 to the present succeed well in depicting the work of the national governments and the leading political figures in the context of the changing social and economic landscapes with which they dealt. Within the overarching teleology of the book, the chapters on the nineteenth century tend to focus more narrowly on political ideas and the narrative of major political events, particularly nationalist groups' relations and conflicts with the imperial states, with emphasis on the Habsburg monarchy. Regrettably, as a result, the transformation of social and economic structures during the nineteenth century and the sociopolitical processes involved in the development of nationalist politics in that era get more cursory treatment.

\footnotetext{
${ }^{8}$ Connelly imputes such a notion of contingency in the development of national loyalties to Judson in his Guardians of the Nation, particularly p. 176.

${ }^{9}$ See Judson, Guardians of the Nation; Zahra, Kidnapped Souls; idem, "Imagined Noncommunities: National Indifference as a Category of Analysis," Slavic Review 69, no. 1 (2020): 93-119; Jeremy King, Budweisers into Czechs and Germans; Bryant, Prague in Black; James Bjork, Neither German nor Pole: Catholicism and National Indifference in a Central European Borderland (Ann Arbor, 2008); Tomasz Kamusella, Silesia and Central European Nationalisms: The Emergence of National and Ethnic Groups in Prussian Silesia and Austrian Silesia, 1848-1918 (West Lafayette, 2006); Gary B. Cohen, The Politics of Ethnic Survival: Germans in Prague, 1861-1914 (Princeton, 1981; rev. 2nd ed., West Lafayette, 2006); and Brendan Karch, Nation and Loyalty in a German-Polish Borderland: Upper Silesia, 1848-1960 (Cambridge, 2020).
}

Cite this article: Cohen GB (2021). John Connelly's Long March through East European History. Austrian History Yearbook 52, 273-279. https://doi.org/10.1017/S0067237821000175 